\title{
Group C streptococcal endocarditis presenting as clinical meningitis: Report of a case and review of the literature
}

ALLEN R HUANG, MD, FRCP, DALIUS J BRIEDIS, MD, FRCP

\begin{abstract}
AR HUANG, DJ BRIEDIs. Group C streptococcal endocarditis presenting as clinical meningitis: Report of a case and review of the literature. Can $J$ Infect Dis 1992;3(5):247-252. Lancefield group C streptococci are known to be pathogenic in a number of animal species, but cause human disease much less commonly than do streptococci of serogroups A or B. Reported cases of bacteremic infection, pneumonia or meningitis in humans have been very severe with a grave prognosis. The authors describe a patient who presented with classic clinical and laboratory evidence of bacterial meningitis which proved to be a complication of endocarditis caused by a group C streptococcus. This is the first reported case in which meningitis was the presenting manifestation of group C streptococcal endocarditis and is only the second case in which group C streptococcal meningitis and endocarditis have been associated in the same patient. A total of 13 cases of group C streptococcal meningitis have now been reported in the medical literature. Five of these patients died, and four others recovered only to be left with neurological sequelae. The current case confirms the seriousness of group $\mathrm{C}$ streptococcal infections in humans. Such infections are associated with a poor prognosis despite apparently adequate antimicrobial therapy.
\end{abstract}

Key Words: Endocarditis, Group C streptococci, Meningitis

\section{Endocardite aux streptocoques du groupe C, accompagnée d'un tableau clinique de méningite: rapport de cas et survol de la littérature}

RÉSUMÉ: Les streptocoques Lancefield du groupe C sont connus pour leur pathogénicité chez certaines espèces animales. Ils occasionnent cependant beaucoup moins fréquemment de maladies chez l'homme que les streptocoques des groupes $\mathrm{A}$ ou $\mathrm{B}$. Les cas déclarés de bactériémie, de pneumonie ou de méningite chez l'homme ont été très graves et ils s'accompagnaient d’un pronostic sombre. Les auteurs décrivent un patient qui présentait des signes cliniques classiques et des épreuves de laboratoire de méningite bactérienne qui s'est révélée être une complication d'une endocardite à streptocoque du groupe C. Il s'agit du premier cas déclaré de méningite dans le contexte d'une endocardite à streptocoque du groupe $\mathrm{C}$ et ce n'est là que le second cas où une méningite et une endocardite à streptocoque du groupe C sont associées chez le même patient. En tout, treize cas de méningite à streptocoque du groupe C ont été rapportés dans la littêrature médicale, cinq de ces patients sont décédés, quatre autres ont gardé des séquelles neurologiques. Le cas actuel confirme la gravité des infections aux streptocoques du groupe C chez l'humain. De telles infections sont associées à un pronostic sombre, malgré l'administration d'un traitement antimicrobien apparemment adéquat.

Divisions of Geriatrics and Infectious Diseases, Department of Medicine. Royal Victoria Hospital. McGill University. Montreal, Quebec.

Correspondence and reprints: Dr Dalius J Briedis. Department of Microbiology and Immunology. 3775 University Street. 
S REPTOCOCCI ASSOCIATED WITH LANCEFIELD SEROGROUP C include those classified as Streptococcus milleri, Streptococcus dysgalactiae (including Streptococcus equisimilis), and Streptococcus equi (including Streptococcus zooepidemicus) (1-4). Streptococci of this serogroup have mainly been described as pathogens in a number of animal species (2,3). Strep equisimilis has been reported to cause septic arthritis and septicemia in swine (3). Strep dysgalactiae causes mastitis in cattle, while Strep equi is the causative agent of strangles, a mucopurulent infection of the upper respiratory tract of horses (1,4). Group C streptococci can be isolated relatively frequently from normal human skin, pharynx and female genital tract $(3,4)$. The use of simplified latex and co-agglutination testing rather than the more timeconsuming precipitin reaction originally described by Lancefield - using heat- and acid-extracted cell wall carbohydrate - has allowed routine serotyping of streptococcal isolates (3). This has led to greater awareness of infections caused by nonserogroup A streptococci. Nonserological methods of identification (including hemolysis reactions, antibiotic sensitivity and fermentation reactions) often left group C streptococci unclassified or misclassified as group A streptococci (3). Reports of group C streptococcal infections in humans have usually described invasion of local tissues $(1,2,5)$. Suppurative tonsillitis and pharyngitis, as well as skin. wound and puerperal infections, have been reported $(1,2,5)$. To the author' knowledge, only 12 cases of meningitis in adults caused by group $\mathrm{C}$ streptococci (including no case with pre-mortem clinical manifestations of both endocarditis and meningitis) have been previously reported in the world literature. The present authors report their experience with a patient with Strep equisimilis endocarditis whose clinical presentation was that of meningitis, and who died despite apparently adequate antimicrobial therapy.

\section{CASE PRESENTATION}

A 67-year-old female known to have rheumatic mitral valvular disease was brought to the hospital because of shortness of breath and altered consciousness. The patient had been previously known to have mitral stenosis associated with chronic atrial fibrillation and had had multiple previous episodes of decom pensated congestive heart failure related to atrial fibrillation with a rapid ventricular response. She had previously refused cardiac catheterization and the possibility of valve replacement surgery. Medications prior to admission consisted of digoxin, diltiazem, furosemide, warfarin and potassium supplementation. The patient had been well until two days prior to admission. There was no history of recent dental, gynecological or urological procedures. There was no history of exposure to pets or other animals. The patient was found by a neighbour who investigated after not having seen her for two days. Immediate history prior to this point was unavailable. The patient appeared short of breath and confused, and was brought to the hospital.

On examination, the patient was an elderly caucasian female who was stuporous. Pulse was 150 beats/min and irregular, blood pressure 130/90 $\mathrm{mmHg}$, respirations $40 / \mathrm{min}$, and temperature $38.8^{\circ} \mathrm{C}$ orally. Examination of the head and neck was notable for marked nuchal rigidity. The fundi were unremarkable. The patient's mouth was edentulous and her throat appeared normal. Examination of the chest revealed only a few scattered wheezes. Examination of the cardiovascular system revealed $8 \mathrm{~cm}$ jugular venous distension. The apex beat was not displaced. Heart sounds were present with an opening snap but without discernible murmur or gallop. Neurological examination revealed a stuporous woman who moved all four limbs equally and withdrew well to painful stimulus. No focal neurological deficits or cranial nerve abnormalities were discernible. Visual fields could not be assessed. The remainder of the physical examination was normal, with no peripheral stigmata of endocarditis.

Hematological evaluation was within normal limits except for a peripheral leukocyte count of 18,900 cells $/ \mathrm{mm}^{3}$ (89\% polymorphonuclear leukocytes) and a prothrombin time of $17.4 \mathrm{~s}$. Initial biochemistry revealed a serum glucose of $10.4 \mathrm{mmol} / \mathrm{L}$, creatine kinase of $1144 \mathrm{U} / \mathrm{L}$, alanine aminotransferase of 62 $\mathrm{U} / \mathrm{L}$, aspartate aminotransferase of $172 \mathrm{U} / \mathrm{L}$, and lactate dehydrogenase of $590 \mathrm{U} / \mathrm{L}$. Electrocardiography demonstrated atrial fibrillation with a ventricular rate averaging 150 beats/min and no acute ischemic changes. A chest radiograph was interpreted as showing interstitial pulmonary edema. Urinalysis was within normal limits. Lumbar puncture yielded clear cerebrospinal fluid with 50 erythrocytes and 400 leukocytes $/ \mathrm{mm}^{3}$ (98\% polymorphonuclear), glucose 5.5 $\mathrm{mmol} / \mathrm{L}$, and protein $540 \mathrm{~g} / \mathrm{L}$. Gram stain of spinal fluid revealed the presence of Gram-positive cocci in chains. Therapy with cefotaxime $6 \mathrm{~g} /$ day was begun immediately after lumbar puncture on the first hospital day.

Echocardiography showed thickened and calcified mitral valve leaflets, as well as a dilated left atrium. which was felt to be consistent with moderate mitral stenosis. No vegetation was identifiable. Computed tomography of the head demonstrated a hypodense area in the left parieto-occipital region associated with effacement of the sulci (Figure 1). No enhancement of the region was noted after infusion of contrast material. The lesion was interpreted as being consistent with a cerebral infarction which had occurred within the past week. In addition, a number of lesions were seen in the area of the basal ganglia, which were interpreted as remote lacunar infarcts.

Strep equisimilis was isolated from spinal fluid culture as well as from all six blood cultures taken prior to 


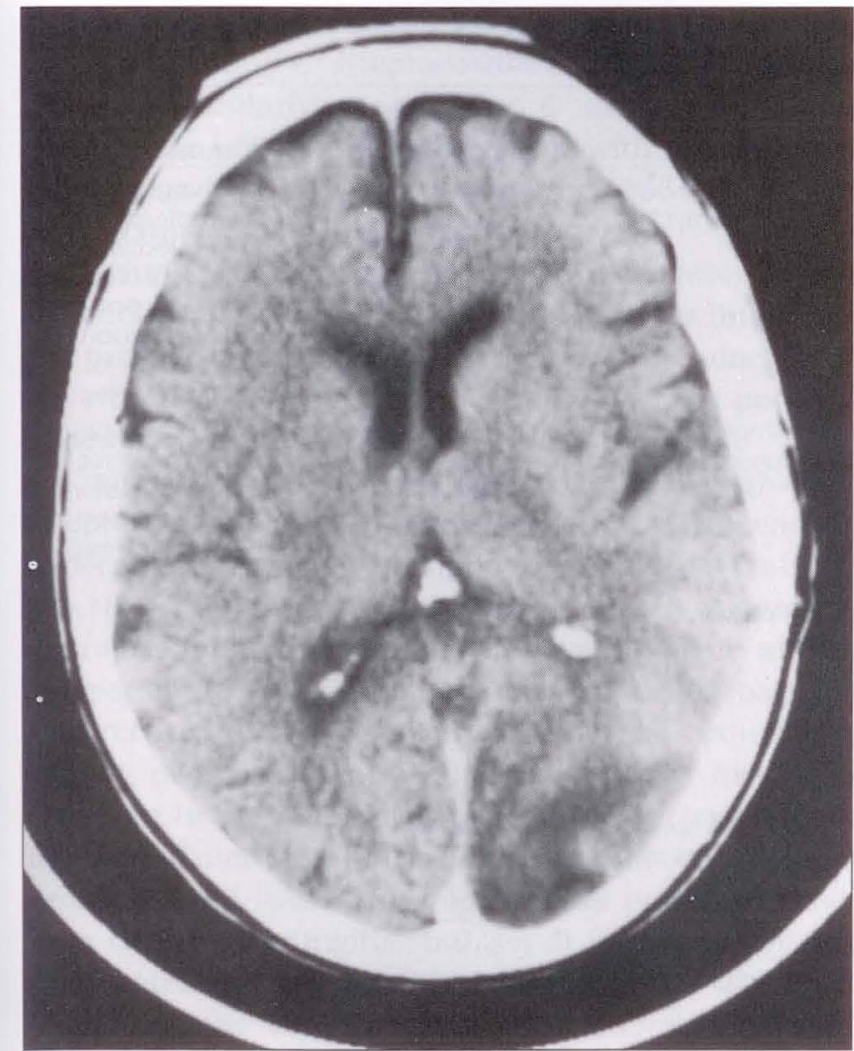

Figure 1) Computed tomographic scan after infusion of contrast material showing a nonenhancing hypodense area in the left parieto-occipital region in a 69-year-old female presenting with shortness of breath and altered consciousness

institution of antibiotic therapy. The organism was beta-hemolytic and susceptible by disc sensitivity test ing to penicillin, oxacillin, cefazolin, vancomycin, erythromycin and cotrimoxazole. The minimal inhibitory and bactericidal concentrations for penicillin $\mathrm{G}$ were equal to or below $0.03 \mathrm{U} / \mathrm{mL}$. Minimal inhibitory and bactericidal concentrations were, respectively, 1.0 and $2.0 \mu \mathrm{g} / \mathrm{mL}$ for gentamicin, 8.0 and $8.0 \mu \mathrm{g} / \mathrm{mL}$ for netilmicin, 6.2 and $6.2 \mu \mathrm{g} / \mathrm{mL}$ for tobramycin, and 4.0 and $16.0 \mu \mathrm{g} / \mathrm{mL}$ for amikacin. Combination therapy with penicillin G 24,000,000 U/day and netilmicin 100 mg every $8 \mathrm{~h}$ was substituted when initial culture results became available on the second hospital day. Intubation and inotropic support became necessary on the second hospital day. After four days of therapy with penicillin and netilmicin, repeat blood cultures were negative, and peak and trough serum bactericidal activities were both greater than 1:5096. Despite antibiotic therapy and diuresis, the patient remained febrile and in mild to moderate congestive heart failure. Repeat spinal fluid examination on the eighth hospital day revealed an absence of cellular elements, a glucose concentration of $5 \mathrm{mmol} / \mathrm{L}$, protein $620 \mathrm{~g} / \mathrm{L}$, negative Gram stain and negative culture. Repeat computed tomography of the head the same day was unchanged from admission. Antibiotic therapy was not altered. By the 10th hospital day the patient had become more

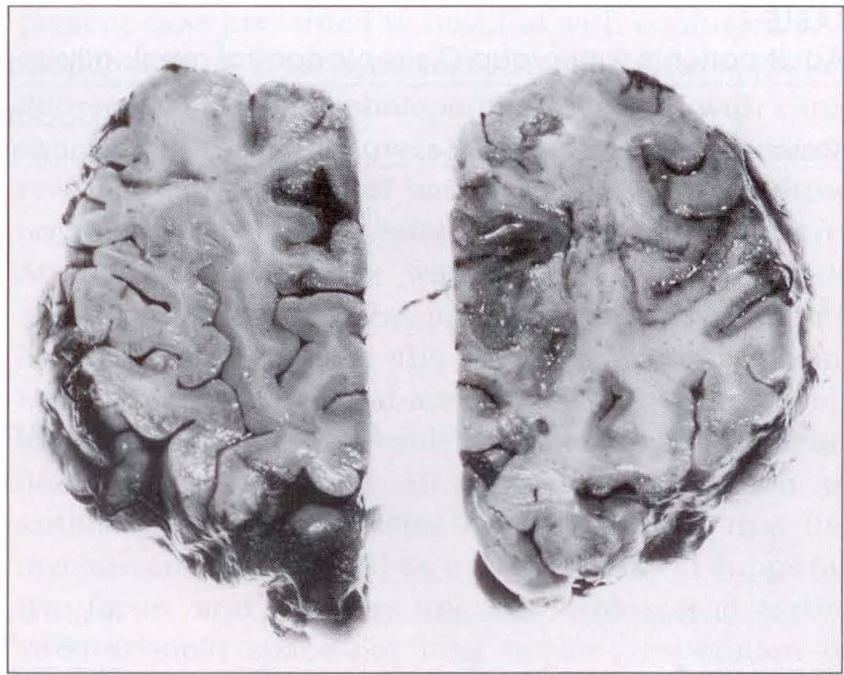

Figure 2) Gross pathological appearance of recent left parietooccipital cerebral infarction in a 69-year-old female with Group $C$ streptococcal meningitis and endocarditis

alert and her nuchal rigidity was improved. She remained respirator dependent, however, and on the 16th hospital day sustained a sudden cardiac arrest. Attempts at resuscitation were unsuccessful.

Autopsy revealed the immediate cause of death to be congestive heart failure and multiple pulmonary emboli. The lungs weighed $1450 \mathrm{~g}$, and multiple recent pulmonary emboli were present on a background of pulmonary edema and emphysema. The heart weighed 360 g. There was evidence of severe atherosclerotic changes in the aorta and coronary arteries, but no myocardial infarct was identified. The left atrium was dilated and a left atrial thrombus was present. A severely thickened mitral valve exhibited fusion of the chordae tendinae and superimposed ulceration associated with friable thrombotic material on the valve surfaces. Colonies of Gram-positive cocci were identified in histological sections of the heart valve. There was no evidence of embolization of thrombotic material to the myocardium. Post mortem culture of the valve material was not performed. The spleen weighed $300 \mathrm{~g}$ and showed passive congestion. Gross examination of the kidneys showed bilateral nephrosclerosis. Histological examination revealed focal glomerulonephritis with immune complex deposition in addition to foci of peritubular and perivascular inflammatory reaction in varying stages of organization, representing probable embolization.

Gross examination of the brain revealed normal-appearing meninges, a normal circle of Willis, and slight softness of the left inferior occipital lobe. Sectioning of the brain allowed identification of an area of recent infarction in the left occipital lobe (Figure 2). Microscopic examination of the brain disclosed multiple cerebral infarcts of various ages in the right frontal lobe, the left cerebellum, and the right lateral occipital lobe. There was histological confirmation of the new left 
TABLE 1

Adult patients with group C streptococcal meningitis reported in the medical literature

\begin{tabular}{|c|c|c|c|c|c|c|c|}
\hline Case & $\begin{array}{c}\text { Year } \\
\text { (reference) }\end{array}$ & Age/Sex & Disease & $\begin{array}{l}\text { Associated } \\
\text { conditions }\end{array}$ & Therapy* & Outcome & Comments \\
\hline 1 & $1970(10)$ & $64 / F$ & $\begin{array}{l}\text { Endocarditis } \\
\text { (mitral): clinically } \\
\text { unsuspected foci of } \\
\text { meningitis at autop- } \\
\text { sy }\end{array}$ & None & $\begin{array}{l}\text { Ampicillin and } \\
\text { streptomycin }\end{array}$ & Died & $\begin{array}{l}\text { Mitral vegetation } \\
\text { with destruction of } \\
\text { anterior leaflet; } \\
\text { early focal areas of } \\
\text { meningitis; post mor- } \\
\text { tem meningeal cul- } \\
\text { tures positive for } \\
\text { group C streptococci }\end{array}$ \\
\hline 2 & $1978(11)$ & $59 / M$ & Meningitis & Farm worker & $\begin{array}{l}\text { Ampicillin and gen- } \\
\text { tamicin: penicillin } G\end{array}$ & $\begin{array}{l}\text { Recovered: se- } \\
\text { quelae of positional } \\
\text { vertigo and incom- } \\
\text { plete hearing loss }\end{array}$ & $\begin{array}{l}\text { Initial bilateral palsies } \\
\text { of cranial nerves III } \\
\text { and VI; respiratory } \\
\text { failure and need for } \\
\text { mechanical respira- } \\
\text { tion }\end{array}$ \\
\hline 3 & $1980(12)$ & $66 / \mathrm{M}$ & Meningitis & $\begin{array}{l}\text { Kept } 4 \text { dogs which } \\
\text { were ill with diar- } \\
\text { rhea and skin infec- } \\
\text { tions but no group } \\
\text { C streptococci } \\
\text { could be cultured } \\
\text { from the animals }\end{array}$ & Penicillin G & Recovered & \\
\hline 4 & $1980(13)$ & $24 / F$ & Meningitis & $\begin{array}{l}\text { Group C strepto- } \\
\text { cocci isolated from } \\
\text { pharynx of patient's } \\
\text { pethorse }\end{array}$ & $\begin{array}{l}\text { Chloramphenicol } \\
\text { and ampicillin: } \\
\text { penicillin } G\end{array}$ & Recovered & \\
\hline 5 & $1982(14)$ & $36 / F$ & $\begin{array}{l}\text { Pneumonia; bac- } \\
\text { teremia; meningitis }\end{array}$ & $\begin{array}{l}\text { Pre-existing partial } \\
\text { gastrectomy }\end{array}$ & $\begin{array}{l}\text { Cephalothin and } \\
\text { gentamicin }\end{array}$ & Died & \\
\hline 6 & $1989(15)$ & $17 / \mathrm{M}$ & $\begin{array}{l}\text { Pansinusitis; } \\
\text { meningitis }\end{array}$ & None & $\begin{array}{l}\text { Penicillin G and } \\
\text { streptomycin }\end{array}$ & Died & \\
\hline 7 & $1989(2)$ & $45 / M$ & Meningitis & $\begin{array}{l}\text { Diabetes; ethanol } \\
\text { and IV drug abuse }\end{array}$ & $\begin{array}{l}\text { Penicillin } G \text { and } \\
\text { cefotaxime: } \\
\text { penicillin } G\end{array}$ & $\begin{array}{l}\text { Recovered: } \\
\text { sequelae of } \\
\text { occipital blindness, } \\
\text { hearing loss and } \\
\text { impaired intellect }\end{array}$ & $\begin{array}{l}\text { Course compli- } \\
\text { cated by subdural } \\
\text { hematoma and } \\
\text { cerebral herniation }\end{array}$ \\
\hline 8 & $1989(2)$ & $23 / M$ & $\begin{array}{l}\text { Subdural em- } \\
\text { pyema; meningitis }\end{array}$ & Unknown & $\begin{array}{l}\text { Penicillin G and } \\
\text { chloramphenicol }\end{array}$ & $\begin{array}{l}\text { Recovered: signifi- } \\
\text { cant neurological } \\
\text { sequelae }\end{array}$ & $\begin{array}{l}\text { Gram-negative or- } \\
\text { ganism also isolated } \\
\text { from CSF; sinus dis- } \\
\text { ease not evaluated }\end{array}$ \\
\hline 9 & $1990(16)$ & $77 / F$ & Otitis: meningitis & Unknown & Penicillin G & Died & \\
\hline 10 & $1990(16)$ & $33 / M$ & Meningitis & None & $\begin{array}{l}\text { Ampicillin and } \\
\text { gentamicin }\end{array}$ & $\begin{array}{l}\text { Recovered; } \\
\text { sequelae of mild } \\
\text { hearing loss }\end{array}$ & \\
\hline 11 & $1990(17)$ & $73 / \mathrm{M}$ & Meningitis & $\begin{array}{l}\text { Alcoholic liver } \\
\text { disease }\end{array}$ & $\begin{array}{l}\text { Penicillin G and } \\
\text { chloramphenicol }\end{array}$ & Recovered & \\
\hline 12 & $1990(18)$ & $24 / \mathrm{M}$ & Meningitis & None & Penicillin $G$ & Recovered & \\
\hline 13 & Present case & $67 / F$ & $\begin{array}{l}\text { Endocarditis } \\
\text { (mitral): mycotic } \\
\text { aneurysm: meningitis }\end{array}$ & $\begin{array}{l}\text { Rheumatic heart } \\
\text { disease }\end{array}$ & $\begin{array}{l}\text { Cefotaxime; } \\
\text { penicillin } G \text { and } \\
\text { netilmicin }\end{array}$ & Died & $\begin{array}{l}\text { Clinical meningitis } \\
\text { at the time of } \\
\text { presentation to } \\
\text { hospital; course } \\
\text { complicated by } \\
\text { pulmonary emboli }\end{array}$ \\
\hline
\end{tabular}

*Initial therapy: subsequent therapy once culture results available: CSF Cerebrospinal fluid

occipital infarct in proximity to a large subarachnoid artery with partial necrosis of its wall associated with a dense inflammatory infiltrate. The lumen of this artery contained a red cell thrombus. The lesion was interpreted as an early mycotic aneurysm despite the absence of discernible bacteria. There was no histological evidence of inflammation of the leptomeninges.

\section{DISCUSSION}

Lancefield group C streptococci are important pathogens in a number of animal species (1). These organisms can be isolated from normal human skin, upper respiratory tract and female genital tract. Infec- tion with group $\mathrm{C}$ streptococci has been associated with suppurative infection of a number of organ systems with an often protracted clinical course and a high mortality $(1,2,5)$. Clinical infections in humans have most commonly involved limited disease including pharyngitis and tonsillitis, as well as skin, wound and puerperal infections (1,2,5-9). Epidemic outbreaks have occurred involving erysipelas in Baltimore in 1924 (6), puerperal fever in London in 1931-32 (7), and acute cellulitis in London in 1944 (8). Serious human disease caused by beta-hemolytic streptococci of serogroup C is, however, much less common than that caused by serogroups A and B. Among 1107 patients with strep- 
tococcal bacteremia at the Mayo Clinic between 1968 and 1977, group C streptococci were identified in only eight (5). Similarly, a serogroup C streptococcus was identified in only one of 140 patients with streptococcal bacteremia during a two-year period (1964-66) at the Massachusetts General Hospital (1).

Beginning with a case of endocarditis described by Rosenthal and Stone in 1940 (9), 21 cases (including the present one) of group $\mathrm{C}$ streptococcal endocarditis have been described. These cases have been partially reviewed by Salata et al (2).

Only 13 cases (including the present one) of group C streptococcal meningitis in the presence or absence of endocarditis have now been reported in adults (Table 1) (10-18). Five of the 13 died, although an apparently appropriate choice of antibiotic(s) was made in all but one patient (case 5, Table 1). Four of the eight patients who recovered were left with neurological sequelae of varying degrees. Three of the cases had a history of exposure to animals. Prior to the present report, only one case of meningitis associated with endocarditis had been reported (case 1, Table 1). This patient did not have clinical meningitis, but small foci of meningitis were noted at autopsy. The present case, therefore, represents the first report of group $\mathrm{C}$ streptococcal endocarditis complicated by clinical meningitis. Group C streptococci have, in addition, been reported as causative agents in five cases of neonatal meningitis (19-22) and in three cases of intracranial abscess or empyema without meningitis $(2,23,24)$.

Various neurological complications have been associated with infective endocarditis. The topic has been reviewed by Lerner et al (25). Embolic events, both bland and septic, are most common. More than $90 \%$ of large emboli to the brain lodge in the anterior cerebral circulation, mainly in the branches of the middle cerebral artery. The present case showed evidence of embolization in the less common distribution of the posterior cerebral circulation. Additional neurological complications of infective endocarditis include the development of mycotic aneurysms, cerebral abscesses, meningoencephalitis and frank meningitis. These may manifest as an acute confusional state with or without focal neurological signs or seizures. The

ACKNOWLEDGEMENTS: We thank Dr I Huttner, Department of Pathology. Royal Victoria Hospital, and Dr S Carpenter. Department of Neuropathology, Montreal Neurological Hospital, for kind assistance in pathological interpretation and photography.

\section{REFERENCES}

1. Duma RJ, Weinberg AN, Medrek TF, Kunz LJ.

Streptococcal infections. Medicine 1969;48:87-127.

2. Salata RA, Lerner PI, Shlaes DM, Gopalakishna KV. Wolinsky E. Infections due to Lancefield group C streptococci. Medicine 1989:68:225-39.

3. Furrow JAE, Collins MD. Taxonomic studies on present case presented to hospital with confusion and stupor without focal neurological signs, as an apparent diffuse or 'toxic' encephalopathy associated with clinical signs of meningitis. Spinal fluid examination revealed classic signs of bacterial meningitis, and the organism was easily isolated from spinal fluid culture. At autopsy, evidence was found for a mycotic aneurysm, but no abscess formation was found and no bacteria were seen in the central nervous system. Despite classical clinical and cerebrospinal fluid findings of meningitis, no evidence of leptomeningeal inflammation was seen 16 days after initiation of antibiotic therapy. It seems likely, therefore, that the mycotic aneurysm acted as a parameningeal suppurative focus, and that the infection had spread to the subarachnoid space not long before presentation to hospital. The clinical course, as well as the absence of leptomeningeal inflammation at autopsy, imply that the death of the patient could not be attributed to either ongoing infection or inadequately aggressive antibiotic therapy.

The clinical presentation of endocarditis as frank meningitis is indeed rare. In a report of 385 patients with bacterial endocarditis diagnosed at the Mayo Clinic (26), 110 patients (29\%) were described as having central nervous system complications. Although 66 of the $110(60 \%)$ had neurological signs or symptoms as their initial manifestation, only seven (6.4\%) had meningitis. In this series, the presence of neurological complications in cases of endocarditis was associated with an overall mortality of $50 \%$ (ranging from $28 \%$, in cases involving viridans streptococci, to approximately $75 \%$ in cases involving Staphylococcus aureus or Enterococcus faecalis).

Group C streptococci are very sensitive in vitro to a number of antibiotics including penicillin $G$, vancomycin, first generation cephalosporins, erythromycin. azlocillin and piperacillin, and newer beta-lactam agents with the exception of moxalactam (27). The present case confirms and adds to the body of literature indicating that, while serious human infections with this serogroup of streptococci are rare, they carry a grave prognosis despite apparently adequate antimicrobial therapy.

streptococci of serological groups C, G, L, and possibily related taxa. System Appl Microbiol 1984:5:483-5.

4. Ruoff KL, Kunz LJ, Ferraro MJ. Occurrence of Streptococcus milleri among beta-hemolytic streptococci isolated from clinical specimens. J Clin Microbiol 1985:22:149-52.

5. Mohr DN, Feist Dj. Washington J, Hermans PE. Infections due to group C streptococci in man. Am J Med 1979:66:450-6.

6. Birkhaug KE. Studies on the biology of the streptococcus erysipelatis. Bull Johns Hopkins Hosp 1925:36:248-53.

7. Colebrook DC. The source of infection in puerperal fever due to hemolytic streptococci. Special Report Series No. 205. Medical Research Council of Great Britain 1935. 
8. Portnoy B. Reitler R. Cellulitis due to a haemolytic streptococcus type C. Lancet 1944:ii:597-8.

9. Rosenthal AH. Stone FM. Puerperal infection with vegetative endocarditis: Report of sulfanilamide therapy in two fatal cases due to Streptococcus haemolyticus groups B and C. JAMA 1940:114:840-7.

10. Bullock JD, Cruz MG, Rabin ER, Sonnenwirth AC. A fatal case of group C streptococcal endocarditis. Missouri Medicine 1970;67:595-8.

11. Mohr DN, Feist DJ, Washington J, Hermans PE. Meningitis due to group $\mathrm{C}$ streptococci in an adult. Mayo Clin Proc 1978:53:529-32.

12. Ghoneim ATM. Cooke EM. Serious infection caused by group C streptococci. J Clin Path 1980;33:188-90.

13. Low DE, Young MR, Harding GKM. Group C streptococcal meningitis in an adult. Arch Int Med 1980;140:977-8.

14. Chung SJ. Meningitis caused by Streptococcus equisimilis (group C). South Med J 1982:75:769.

15. Arditi M, Shulman ST, Davis T, Yogev R. Group C $\beta$-hemolytic streptococcal infection in children: Nine pediatric cases and review. Rev Infect Dis 1989:1 1:34-45.

16. Patey O. Buisson CB. Soussy CJ. Group C streptococcal meningitis in adults. Rev Infect Dis 1990:12:157-8.

17. Mollison LC, Donaldson E. Group C streptococcal meningitis. Med J Aust 1990:152:319-20.

18. Cheeseman M, Genain C, Smith CD. Group C streptococcal meningitis with favorable recovery: A case report. J Ky Med Assoc 1990:88:545-6.

19. Delaitre R, Fossee F. Cayeux P. Parvery F. Meningites purulentes a streptocoques du groupe C. A propos de 2 observations chez un nouveaune et un nourrisson de 44 heures. Pediatrie 1972:27:181-5.

20. Hervas JA, Labay MV, Rullan G, Aguilar GLJ, Alomar P. Neonatal sepsis and meningitis due to Streptococcus equisimilis. Pediatr Infect Dis 1985:4:694-5.

21. Quinn RJM, Hallet AF, Path MRC, Applebaum PC, Cooper RC. Meningitis caused by Streptococcus dysgalactiae in a preterm infant. Am J Clin Path 1978:70:948-50.

22. Steardson-Kreigar P, Gotoff SP. Neonatal meningitis due to group C beta-hemolytic streptococcus. J Pediatr 1977:90:103-4.

23. Dinn JJ. Brain abscess due to Streptococcus equisimilis in a malt-worker. J Ir Med Assoc 1971:64:50-1.

24. Layon J. McCulley D. Subdural empyema and group C streptococcus. South Med J 1985:78:64-6.

25. Lerner PI. Neurologic complications of infective endocarditis. Med Clin N Am 1985:69:385-96.

26. Hermans PE. The clinical manifestations of infective endocarditis. Mayo Clin Proc 1982;57:15-23.

27. Ralston KV, Le Frock JL, Schell RF. Activity of nine antimicrobial agents against Lancefield group C and G streptococci. Antimicrob Agents Chemother 1982:22:930-3. 


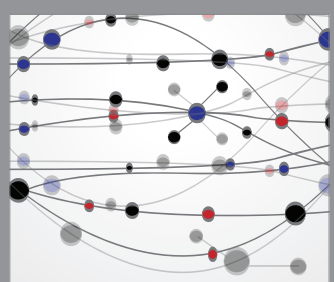

The Scientific World Journal
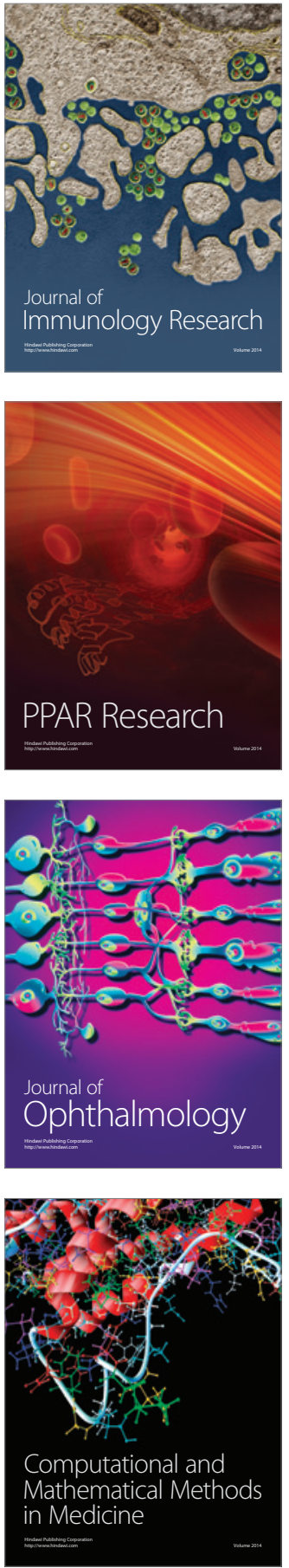

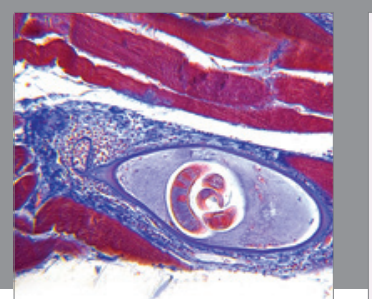

Gastroenterology Research and Practice

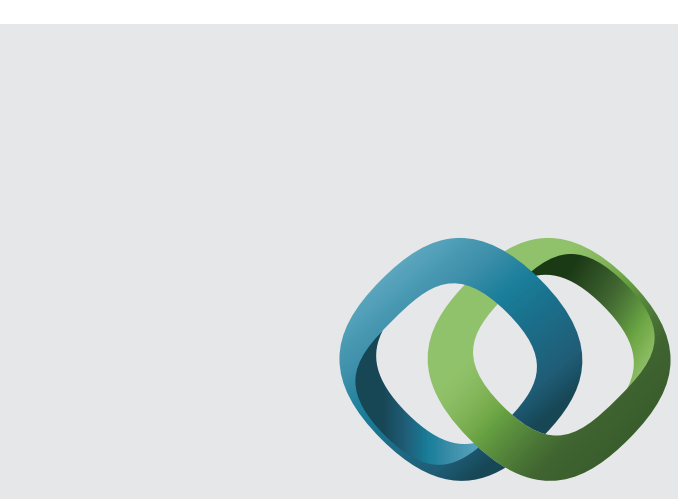

\section{Hindawi}

Submit your manuscripts at

http://www.hindawi.com
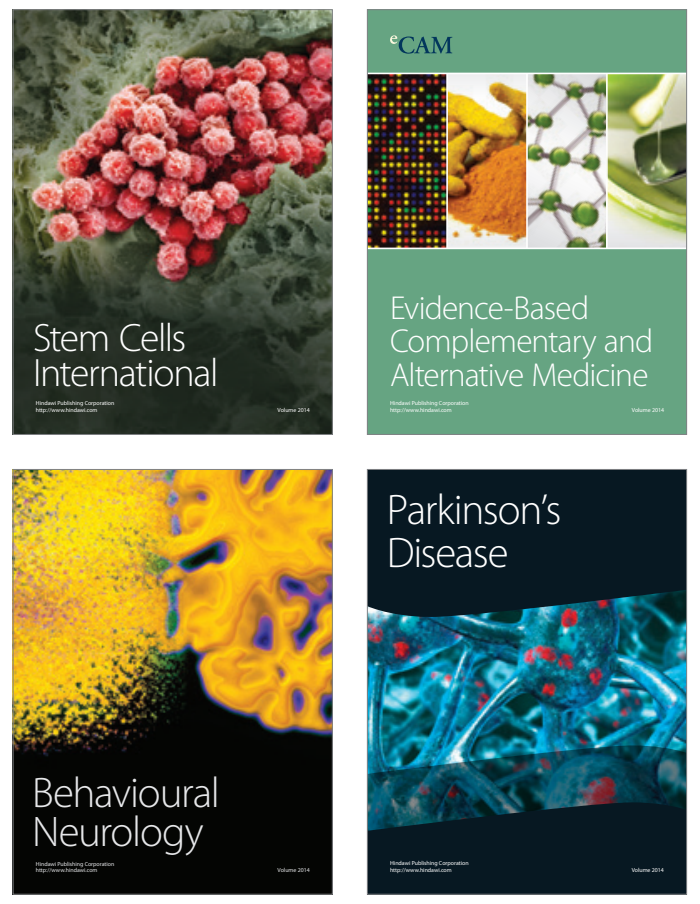
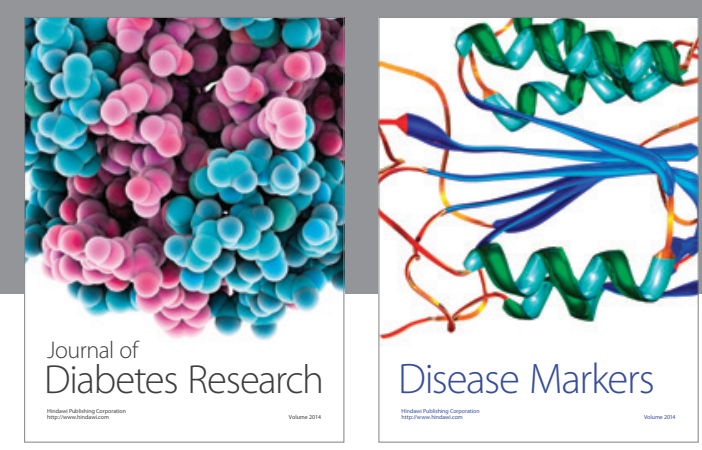

Disease Markers
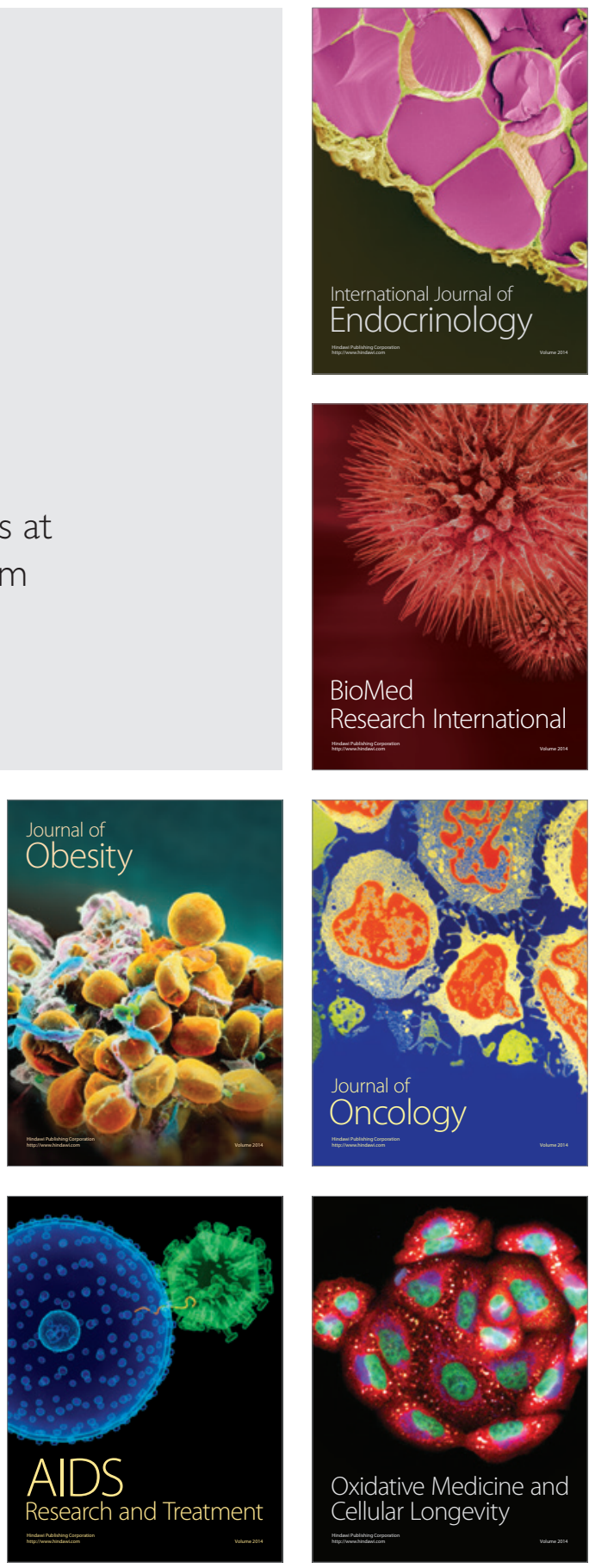